\title{
Combining ability and heterosis analysis for fibre yield and quality parameters in roselle (Hibiscus sabdariffa $\mathbf{L}$.)
}

\author{
Hariom Kumar Sharma*, Shashi Bhushan Choudhary, A. Anil Kumar, R. T. Maruthi and \\ S.K. Pandey
}

Crop Improvement Division, ICAR-Central Research Institute for Jute and Allied Fibres, Barrackpore, Kolkata- 700120 (West Bengal), INDIA

*Corresponding author. E-mail: harrygpb@gmail.com

Received: May 28, 2017; Revised received: July 15, 2017; Accepted: November 10, 2017

\begin{abstract}
Roselle (Hibiscus sabdariffa L.) is second important bast fibre crop after jute in India. With an aim to exploit non-additive genetic variance present experiment was designed to identify good general combining parents and specific cross combination for fibre yield and fibre quality parameters (fibre fineness, fibre tenacity) in roselle. A total of 11 parents were crossed in complete diallel fashion which resulted $55 F_{1}, 55 R_{1}$ (reciprocal $F_{1}$ ). Parents, $F_{1} s$ and $\mathrm{RF}_{1} \mathrm{~s}$ were grown in randomized block design. Analysis of variance revealed significant differences $(P<0.01$, $P<0.05)$ among the parents and their hybrids. The parents AMV 1, AMV 5, GR 27 and AHS 160 were identified as good combiners since they recorded significant general combining ability (GCA) effects for fibre yield and quality parameters. Further, For fibre yield only three crosses (AMV $1 \times$ AMV 4, AMV $1 \times$ GR 27, HS 4288 × JRR 07) showed significant specific combining ability (SCA) effects from them hybrid AMV $1 \times$ GR 27 (fibre yield=27.37g/ plant) exhibited positively significant best parent (Non bris 4, Mean fibre yield=21.16g/plant) heterosis (29.35\%). Similarly, for fibre tenacity, hybrid GR $27 \times$ JRR 07 (fibre tenacity=23.47g/tex) exhibited positively significant best parent (HS 4288; fibre tenacity $=20.35 \mathrm{~g} /$ tex) heterosis $(15.30 \%)$.
\end{abstract}

Keywords: Roselle, Hibiscus sabdariffa L., Fibre, Combining ability, Heterosis

\section{INTRODUCTION}

Mesta is a common term used for two bast fibre crops namely roselle (Hibiscus sabdariffa L.) and kenaf (Hibiscus cannabinus L.). Among the two species, roselle is more important in India since $80 \%$ of total mesta growing area is occupied by roselle (Karmakar et al., 2008). There are two botanical types of roselle. First one $H$. sabdariffa var. altissima, primarily cultivated for its jute-like fiber in India, the East Indies, Nigeria and to some extent in tropical America. While the other one H. sabdariffa var. sabdariffa mainly cultivated for its edible calyx production (Mortan, 1987; Da-Costa-Rocha et al., 2014, Sharma, 2016). Roselle was first domesticated in western Sudan before 4000 BC (Mortan, 1987) and tropical Africa appears to be a major centre of diversity (Duke, 1983). It has been widely distributed in the tropics and subtropics of both hemispheres (Mostafa et al., 2005). In India it is primarily cultivated for the bast fibre production in West Bengal, Bihar, Andhra Pradesh, Maharashtra, Odisha, Karnataka, Tamil Nadu and Tripura (Karmakar et al., 2008). Roselle fibre is coarser than jute hence used along with jute, kenaf and other natural fibres for making of ropes, twines, hessian, sacks, geo-textiles and other cordage products (Wester, 1907, Da-CostaRocha et al., 2014, Sharma et al., 2016).
Till 2016 a total of 12 varieties of roselle have been developed for fibre production (Anonymous, 2017). In 2015-16 estimated mesta production was 5.68 lakh bales $(1$ bale $=180 \mathrm{~kg})$ and in same year India imported 87.6 thousand Ton raw jute (jute and mesta) to meet the export demand of jute and jute goods (Anonymous, 2016). Hence in order to meet this demand and to compete with low cost synthetic fibre there is a need to further increase the productivity of jute and mesta crop. It is well known that the yield of hybrids in any crops is higher in comparison to pureline varieties developed through selection and pedigree method of breeding. In India, until now, commercial hybrids of mesta have not been developed whereas China has released some hybrids in kenaf (Li, 2002).

The success of any breeding program depends largely on two aspects; (a) selection of superior parents (b) the type of gene action involved in the expression of target character. An understanding of combining ability of the parents, especially when the objective is to develop hybrid cultivar, is very much prerequisite for augmenting the breeding strategy. Information on combining ability is needed to identify potentially superior parents and hybrids and would help to define the pattern of gene effects in the expression of quantitative traits (Goyal and Kumar, 1991). The knowledge of nature of 
gene action for fibre yield and its component traits in the breeding material can provide useful information for selecting proper breeding procedure for future genetic enhancement. Most of the research work in the crop related to combining ability and heterosis has been reported for calyces, seed yield and oil content (Thirthamallappa and Sheriff, 1992; Tejaswini and Sarma, 1995; Mukewar et al., 1997; Ibrahim and Hussein, 2006; Ruelas-Hernandez et al., 2008) since the calyces are used as refrigerant in the form of tea, to make jellies and jams and its oil is good source of unsaturated fatty acids, mainly linoleic acid (Mahadevan et al., 2009; Da-Costa-Rocha et al., 2014, Sharma et al., 2016). However, the literature regarding heterosis studies for fibre yield and quality in this crop is scanty. Keeping these views, the present work was designed to assess the general and specific combining abilities in respect of fibre yield and attributing traits of eleven parents and 110 hybrids of roselle.

\section{MATERIALS AND METHODS}

Experiment was conducted at experimental field of ICAR-CRIJAF, Barrackpore, Kolkata, India. A total of 11 genotypes (AMV 1, AMV 2, AMV 3, AMV 4, AMV 5, HS 4288, GR27, Non bris 4, HS 7910, AHS 160 and JRR 07) including already developed varieties (AMV 1, AMV 2, AMV 3, AMV 4, AMV 5, HS 4288, GR27, Non bris 4, HS 7910) of roselle were crossed in complete diallel fashion to generate 110 hybrids. For crossing sowing was done in last week of August. After flower initiation mature flower bud which was likely to open in the next morning was emasculated in afternoon (3.00 pm to $4.00 \mathrm{pm})$ and crossed next morning (7.00 am to $9.30 \mathrm{am}$ ) using pollens from male parent. Crossed pods were collected after maturity nearly after 140-160 days after sowing (DAS) and seeds were extracted manually. Hundred and ten hybrids $\left(55 F_{1 s}\right.$ and 55 Reciprocal $\left.F_{1 s}\right)$ and 11 parents were evaluated using randomised block design with three replications in next growing season. Each geno- type was grown in a row of $3 \mathrm{~m}$ length at $30 \mathrm{~cm}$ row spacing in first week of June. Further, plant to plant spacing within a row was maintained by thinning at 5$7 \mathrm{~cm}$ distance after 21 DAS. All recommended package of practices was followed to raise the stress free crop. Data was collected on fibre yield and its attributing traits (Table 1) on five randomly selected plants at 140 days after sowing. Mean data for 5 plants was used for further data analysis. Analysis of variance (ANOVA) for the recorded traits, combining ability and diallel analysis was done using Windostat statistical software (WINDOSTAT ver. 9.1) following Grifings numerical approach Method 1 with fixed effect model described by (Singh and Chaudhary, 1979).

\section{RESULTS AND DISCUSSION}

ANOVA revealed significant $(P<0.01, P<0.05)$ differences among the genotypes (parents and hybrids) for all fibre yield and quality parameters except number of nodes/plant (Table 1). Likewise a significant difference between parents vs. hybrids was observed indicating presence of heterosis in hybrids for fibre yield and attributing traits. Non-significant difference was noticed between $F_{1 s}$ and $R_{1 s}$ for all the traits except fibre fineness, indicating absence of maternal effect in roselle crosses.

The GCA effects for fibre yield and quality characters of eleven parental lines are presented in table 2. The results revealed that parent AMV 1 had significantly positive GCA effect for basal diameter (0.543), internode length (1.619) and fibre yield (1.56). A positive GCA effect is desired for plant height to get a taller stature combination. Parent AMV 5 had significantly positive GCA effect for plant height (7.62), fibre tenacity (0.324) and parent GR 27 recorded significant positive GCA effects for plant height (11.37), green weight (25.65), fibre weight (1.41), stick weight (3.15) and fibre tenacity $(0.45)$. The overall study of GCA effects of parents suggested that from fibre yield point of view two parent namely, AMV 1 and GR 27 while

Table 1. Analysis of variance (ANOVA) for fibre yield and quality parameters in roselle.

\begin{tabular}{|c|c|c|c|c|c|c|c|c|c|c|}
\hline Source & $D f$ & Pht & Bd & Gwt & Nod & Inod & Fwt & Swt & Ft & Ff \\
\hline Genotypes & 120 & $797.09 * *$ & $5.05^{*}$ & $8263.81 *$ & 99.85 & $41.36^{*}$ & $22.98 * *$ & $202.54 * *$ & $14.07 * *$ & $0.48^{* *}$ \\
\hline Parents & 10 & $1178.67 * *$ & 3.393 & 6610.788 & 94.87 & 43.811 & 19.55 & 187.728 & $28.20 * *$ & $0.26 * *$ \\
\hline Hybrids & 109 & $751.57 * *$ & $5.03 *$ & 7785.16 & 84.642 & $40.95 *$ & $22.90 * *$ & $200.39 * *$ & $12.70 * *$ & $0.50 * *$ \\
\hline Parent & & & & & & & & & & \\
\hline Hybrid & 1 & $1943.44 * *$ & $24.33 * *$ & $76967.28 * *$ & $1808.31 * *$ & 61.261 & $66.03 *$ & $584.22 *$ & $21.79 * *$ & $0.46^{* *}$ \\
\hline $\mathrm{F}_{1}{ }^{\prime} \mathrm{s}$ & 54 & $713.81 * *$ & $5.27 * *$ & $8409.32 *$ & 78.075 & 31.02 & $23.69 * *$ & $256.86 * *$ & $19.06 * *$ & $0.46^{* *}$ \\
\hline $\begin{array}{l}\text { Reciprocals } \\
\left(\mathrm{RF}_{1} \mathrm{~s}\right)\end{array}$ & 54 & $800.46^{* *}$ & 4.88 & 7304.087 & 92.54 & $50.10 * *$ & $22.54 * *$ & 145.794 & $6.23 * *$ & $0.55^{* *}$ \\
\hline $\begin{array}{l}\mathrm{F}_{1} \text { Vs. Recipro- } \\
\text { cal }\end{array}$ & 1 & 150.649 & 0.075 & 58.548 & 12.521 & 83.533 & 0.003 & 100.21 & 18.627 & $0.66^{* *}$ \\
\hline Error & 240 & 355.48 & 3.56 & 6033.015 & 78.058 & 29.207 & 12.256 & 127.78 & 1.924 & 0.054 \\
\hline Total & 362 & 538.746 & 4.659 & 8123.507 & 108.78 & 34.096 & 16.709 & 171.383 & 5.975 & 0.197 \\
\hline
\end{tabular}

*, ** Significance at $\mathrm{P}<0.05$ and $\mathrm{P}<0.01$, respectively, Pht: plant height $(\mathrm{cm})$, Bd: basal stem diameter (mm), Gwt: green plant weight without leaves $(\mathrm{g})$, Nod: no. of nodes, Inod: internode length $(\mathrm{mm})$, Fwt: dry fibre weight $(\mathrm{g})$, Swt: dry stick weight without fibre (g), Ft: fibre tenacity (g/tex), Ff: fibre fineness (tex) 
for fibre tenacity three parents (AMV 5, GR 27 and JRR 07) were found to possess significantly positive GCA effects. Further, for fibre fineness only two parents (AMV 5, AHS 160) had significant negative GCA effects. In a similar line of work Thirthamallappa and Sheriff (1992) also reported significant positive GCA effect for majority of traits tested in a $10 \times 10$ diallel set of roselle. Since the GCA effect is controlled by stable additive gene effects, parents with significant
GCA effects are considered to be good combiners and inclusion of such genotypes in breeding program can accelerate yield improvement process (Dar et al. 2016). Hence for improvement of fibre yield and quality these lines could be used as parents in breeding program.

The effectiveness of a particular cross in exploiting heterosis is decided by the SCA effect of $\mathrm{F}_{1}$. According to Sprague and Tatum (1942) the SCA is con-

Table 2. General combining ability (GCA) effect of eleven parents for fibre yield and quality parameters in roselle.

\begin{tabular}{|c|c|c|c|c|c|c|c|c|}
\hline Parents & Pht & Bd & Gwt & Inod & Fwt & Swt & $\mathbf{F t}$ & Ff \\
\hline P1 (AMV-1) & -4.021 & $0.543^{*}$ & 7.423 & $1.619 *$ & $1.56^{* *}$ & 2.732 & -0.09 & -0.048 \\
\hline P2 (AMV-2) & -2.529 & -0.007 & 15.044 & $-1.636^{*}$ & 0.108 & 2.112 & $-0.55 * *$ & 0.044 \\
\hline P3 (AMV-3) & -3.873 & -0.373 & -16.865 & -0.806 & -0.509 & -0.911 & 0.249 & -0.004 \\
\hline P4 (AMV-4) & 1.037 & -0.168 & -3.729 & -0.105 & 0.032 & 0.244 & -0.09 & $0.093 * *$ \\
\hline P5 (AMV-5) & $7.62 * *$ & -0.075 & 9.923 & $-1.368 *$ & 0.373 & 1.602 & $0.324 *$ & $-0.14 * *$ \\
\hline P6 (HS-4288) & 2.784 & 0.072 & 5.105 & $1.868 * *$ & -0.026 & 1.549 & 0.231 & -0.048 \\
\hline P7 (GR-27) & $11.37 * *$ & 0.275 & $25.65 * *$ & -0.943 & $1.41 * *$ & $3.148 *$ & $0.451 * *$ & -0.032 \\
\hline P8 (Nonbris- 4) & -1.155 & -0.399 & $-18.244 *$ & 1.098 & $-1.22 * *$ & $-3.77 * *$ & $-0.64 * *$ & 0.013 \\
\hline P9 (AHS-160) & -1.869 & -0.076 & -0.729 & -0.387 & -0.756 & $-2.94 *$ & $-0.53 * *$ & $-0.14 * *$ \\
\hline P10 (JRR-07) & $-7.583 * *$ & -0.134 & $-18.66^{*}$ & $-1.44 *$ & -0.187 & -1.853 & $1.23 * *$ & $0.238 * *$ \\
\hline P11 (HS-7910) & -1.789 & 0.342 & -4.91 & $2.103 * *$ & -0.787 & -1.902 & $-0.59 * *$ & 0.033 \\
\hline
\end{tabular}

*, ** Significance at $P<0.05$ and $P<0.01$, respectively, Pht: plant height $(\mathrm{cm})$, Bd: basal stem diameter $(\mathrm{mm})$, Gwt: green plant weight without leaves (g), Nod: no. of nodes, Inod: internode length (mm), Fwt: dry fibre weight (g), Swt: dry stick weight without fibre (g), Ft: fibre tenacity (g/tex), Ff: fibre fineness (tex)

Table 3. Specific combining ability (SCA) effect of different crosses of roselle.

\begin{tabular}{|c|c|c|c|c|c|c|c|c|c|}
\hline Crosses & Pht & Bd & Gwt & Nod & Inod & Fwt & Swt & $\mathbf{F t}$ & Ff \\
\hline P1xP2 & $26.51 * *$ & -0.205 & 37.759 & 2.438 & $-4.832 *$ & 0.433 & 2.357 & 0.225 & $-0.23 * *$ \\
\hline P1xP3 & -12.126 & 0.387 & 21.335 & $8.169^{*}$ & 1.961 & 1.305 & 4.268 & 0.392 & -0.047 \\
\hline $\mathrm{P} 1 \times \mathrm{P} 4$ & 9.914 & 0.62 & 18.698 & 2.527 & 1.027 & $5.906 * *$ & $9.596^{*}$ & -0.385 & 0.006 \\
\hline P1xP5 & -5.004 & 1.243 & 7.214 & -0.486 & -1.218 & 0.488 & 3.916 & 0.384 & $-0.268 * *$ \\
\hline $\mathrm{P} 1 \mathrm{xP} 6$ & $14.878^{*}$ & 0.958 & $59.365^{*}$ & 4.101 & 1.242 & 1.517 & $9.441 *$ & -0.63 & 0.131 \\
\hline P1xP7 & 7.325 & $2.023 * *$ & 34.153 & 4.186 & -3.036 & $3.067 *$ & $9.392 *$ & -0.92 & -0.002 \\
\hline P1xP9 & -6.139 & -0.521 & -11.635 & -0.598 & 0.709 & -0.882 & -3.141 & $1.323 *$ & 0.089 \\
\hline P1xP10 & -0.835 & -0.233 & -6.529 & 0.963 & 0.23 & -2.522 & -6.968 & $2.443 * *$ & 0.069 \\
\hline $\mathrm{P} 2 \mathrm{xP} 4$ & $-32.64 * *$ & 0.723 & -13.923 & -2.08 & -0.558 & -0.339 & -1.822 & $-1.09 *$ & -0.095 \\
\hline $\mathrm{P} 2 \mathrm{xP} 6$ & 7.842 & -0.619 & -23.923 & 1.441 & 0.509 & -0.843 & -1.322 & $-1.42 * *$ & $-0.17 *$ \\
\hline P2xP7 & -2.967 & 0.054 & 10.032 & -0.02 & 0.324 & -0.845 & 1.06 & $2.003 * *$ & $-0.24 * *$ \\
\hline P2xP9 & -4.267 & 1.096 & 19.077 & 1.6 & 0.492 & 2.211 & 6.822 & $1.802 * *$ & $0.297 * *$ \\
\hline $\mathrm{P} 2 \mathrm{xP} 11$ & 1.015 & -0.455 & -23.574 & 3.631 & -1.343 & -0.236 & -1.787 & 0.023 & $-0.309 * *$ \\
\hline $\mathrm{P} 3 \times \mathrm{P} 4$ & -3.993 & -0.686 & -19.014 & -4.106 & 0.127 & -2.036 & -3.936 & 0.001 & $-0.306^{* *}$ \\
\hline P3xP9 & 9.079 & 0.263 & 4.653 & 2.269 & -1.566 & 0.925 & 3.319 & -0.725 & $-0.289 * *$ \\
\hline $\mathrm{P} 3 \times \mathrm{P} 10$ & -9.314 & -0.282 & -19.074 & -0.428 & 2.613 & -1.815 & -3.122 & $4.49 * *$ & -0.092 \\
\hline P4xP8 & -1.018 & -0.187 & -11.802 & $7.714^{*}$ & -1.886 & -1.505 & 0.172 & -0.677 & $0.186^{*}$ \\
\hline P4xP9 & 13.586 & 0.823 & 50.517 & 2.668 & -0.383 & -0.079 & 1.398 & 0.833 & $-0.28 * *$ \\
\hline $\mathrm{P} 4 \mathrm{xP} 11$ & 2.415 & -0.224 & 9.865 & -3.976 & -0.34 & 0.949 & 3.835 & $1.184^{*}$ & $0.191^{*}$ \\
\hline P5xP6 & $-19.71 * *$ & -1.124 & -43.302 & -4.854 & 0.282 & -2.573 & $-11.39 * *$ & -0.145 & 0.123 \\
\hline P5xP7 & 3.819 & -0.286 & 2.986 & 0.102 & -0.27 & 1.004 & 2.561 & -0.386 & $-0.29 * *$ \\
\hline P5xP8 & 5.425 & 1.023 & 50.38 & 5.692 & -1.568 & 0.16 & 3.519 & $2.141 * *$ & -0.088 \\
\hline P5xP11 & $17.208 *$ & $1.571 *$ & $62.214^{*}$ & 4.958 & 1.667 & 2.206 & $11.551 * *$ & -0.117 & -0.149 \\
\hline P6xP10 & $14.55^{*}$ & $1.765 *$ & $85.789 * *$ & 3.936 & 0.581 & $3.689 * *$ & $13.731 * *$ & $-1.202 *$ & $0.186^{*}$ \\
\hline P7xP8 & -12.652 & 0.623 & -20.68 & 1.961 & 0.848 & -1.809 & -0.198 & 0.581 & $-0.24 * *$ \\
\hline P7xP9 & $14.214^{*}$ & 1.204 & 52.638 & $7.944^{*}$ & 0.504 & 1.624 & 2.202 & -0.352 & -0.143 \\
\hline $\mathrm{P} 7 \mathrm{xP} 10$ & 5.304 & -0.592 & -5.256 & 1.544 & 0.545 & -0.458 & -1.961 & $2.174^{* *}$ & $0.22 *$ \\
\hline P8xP10 & 7.802 & 0.139 & -5.362 & 3.2 & 0.084 & 2.264 & 3.469 & $-1.59 * *$ & $-0.62 * *$ \\
\hline P8xP11 & 0.913 & 0.542 & 20.547 & -0.839 & $4.878^{*}$ & 1.002 & -1.327 & $-1.77 * *$ & 0.013 \\
\hline P10xP11 & 2.61 & -0.757 & -28.029 & 3.711 & 0.088 & -0.937 & -1.406 & $-1.66 * *$ & $-0.18 *$ \\
\hline $\mathrm{CD}(\mathrm{Sij}) 5 \%$ & 14.099 & 1.411 & 58.083 & 6.607 & 4.041 & 2.618 & 8.453 & 1.037 & 0.173 \\
\hline $\mathrm{CD}$ (Sij) $1 \%$ & 18.776 & 1.879 & 77.351 & 8.798 & 5.382 & 3.486 & 11.257 & 1.381 & 0.231 \\
\hline
\end{tabular}

*, ** Significance at $P<0.05$ and $P<0.01$, respectively, Pht: plant height $(\mathrm{cm}), \mathrm{Bd}$ : basal stem diameter (mm), Gwt: green plant weight without leaves (g), Nod: no. of nodes, Inod: internode length ( $\mathrm{mm})$, Fwt: dry fibre weight (g), Swt: dry stick weight without fibre (g), Ft: fibre tenacity (g/tex), Ff: fibre fineness (tex) 


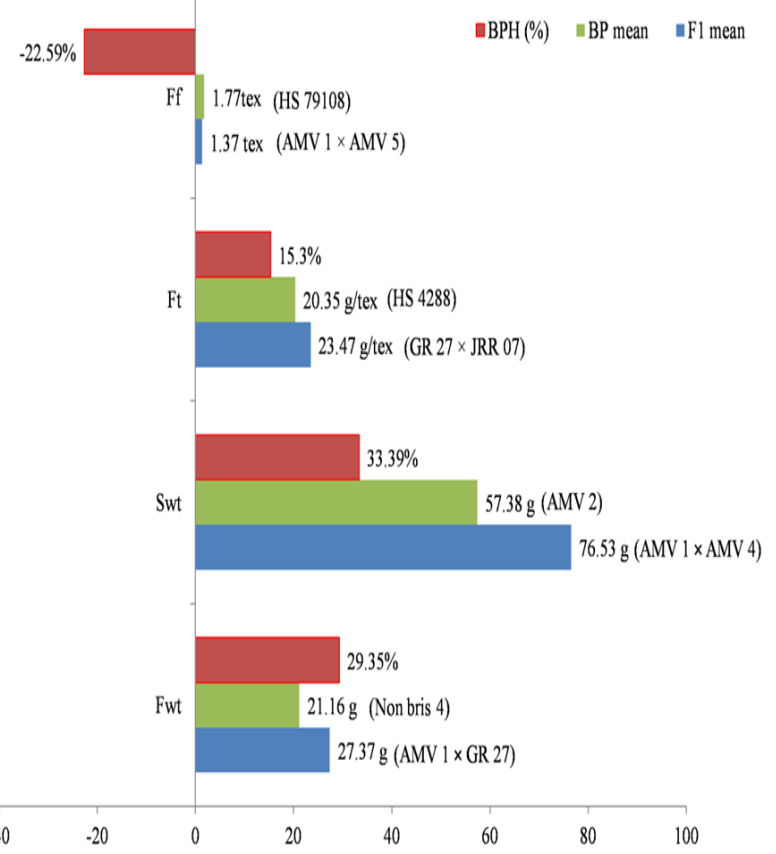

Fig. 1. Best parent heterosis (BPH) of top four roselle crosses.

Fwt: dry fibre weight (g), Swt: dry stick weight without fibre (g), Ft: fibre tenacity (g/tex), Ff: fibre fineness (tex)

trolled by non-additive gene action and is an important criterion for the evaluation of hybrids. The results of SCA effects revealed some useful cross combinations with significant positive SCA effects for fibre yield and quality parameters (Table 3 ). For fibre yield only three crosses (AMV $1 \times$ AMV 4, AMV $1 \times$ GR 27, HS $4288 \times$ JRR 07) showed significant SCA effects. On other hand, for fibre tenacity significant SCA effects were recorded by eight crosses and significant negative SCA effects for fineness were noticed in twelve crosses. Significant SCA value for fibre yield and quality traits was observed even in the crosses involving parents either or both were poor combiner for fibre yield and other related traits. Crosses with high $\times$ low and low $\times$ low general combiner exhibiting high SCA effects were explained by Jinks (1956) as due to overdominance and epistasis. The best three specific combiners for fibre tenacity were AMV $3 \times$ JRR 07, AMV $1 \times$ JRR 07, GR $27 \times$ JRR 07 and Non bris $4 \times$ JRR 07, AMV $2 \times$ HS 7910, AMV $3 \times$ AMV 4 were for fibre fineness. Therefore, these hybrids are of considerable practical importance and can be directly used to exploit heterosis for these traits. In cross AMV $1 \times$ GR 27 both parents expressed positively significant GCA effects for fibre yield hence this hybrid is recommended for recombination breeding.

As far as heterosis is concerned hybrid AMV $1 \times$ GR 27 (fibre yield $=27.37 \mathrm{~g} /$ plant) exhibited positively significant best parent (Non bris 4, Mean fibre yield $=21.16 \mathrm{~g} /$ plant) heterosis $(29.35 \%)$ (Fig.1). Simi- larly, for fibre tenacity hybrid GR $27 \times$ JRR 07 (fibre tenacity $=23.47 \mathrm{~g} /$ tex $)$ exhibited positively significant best parent (HS 4288; fibre tenacity $=20.35 \mathrm{~g} /$ tex) heterosis (15.30\%). For fibre fineness cross AMV $1 \times \mathrm{AMV}$ 5 (fibre fineness $=1.37$ tex) showed highly significant negative heterosis $(-22.59 \%)$ over best parent (HS 7910, fineness $=1.77$ tex $)$.

\section{Conclusion}

Fibre yield, fibre tenacity and fibre fineness are important traits in roselle. Thus, the identified parents (AMV 1, AMV 5, GR 27, AHS 160) which exhibited significant GCA effects for different fibre yield and quality attributes can be used for further improvement of these traits. One cross each for fibre yield (AMV $1 \times$ GR 27), fibre tenacity (GR $27 \times$ JRR 07) and fibre fineness (AMV $1 \times$ AMV 5) were identified hence these have been recommended for heterosis breeding of these traits. Our study is the stepping stone towards exploitation of non-additive genetic variance as the identified crosses can be used for exploitation hybrid vigour which is still untapped for improvement of a minor bast fibre crop like roselle.

\section{ACKNOWLEDGEMENTS}

Authors are thankful to Director ICAR-Central Research Institute for Jute and Allied Fibres, Barrackpore, Kolkata, India for providing resources and facilities for conducting the experiment.

\section{REFERENCES}

Anonymous (2016). Sixth annual report 2015-16, National Jute Board. 79p.

Anonymous (2017). http://www.crijaf.org.in/SideLinks/ Research/Varieties.html. accessed on 12-05-2017.

Da-Costa-Rocha, I., Bonnlaender, B., Sievers, H., Pischel, I. and Heinrich, M. (2014). Hibiscus sabdariffa L. - A phytochemical and pharmacological review. Food Chem., 165: 424-443.

Dar, Z.A., Wani, S.A. and Wani, M.A. (2016). Heterosis and combining ability analysis for seed yield and its attributes in Brassica rapa ssp. Brown sarson. J. Oilseed Brass, 2: 21-28.

Goyal, S.N. and Kumar, S. (1991). Combining ability for yield component and oil content in sesame. Indian $J$. Genet. Plant Breed., 51: 311-314.

Ibrahim, M.M. and Hussein, R.M. (2006). Variability, heritability and genetic advance in some genotypes of roselle (Hibiscus sabdariffa L.). World J. Agric. Sci., 2(3):340-345.

Jinks, J.L. (1956). The $F_{2}$ and backcross generations from a set of diallel crosses. Heredity, 10: 1-30.

Karmakar, P.G., Hazra, S.K., Sinha, M.K. and Chaudhury, S.K. (2008). Breeding for quantiative traits and varietal development in jute and allied fibres. In: Karmakar, P.G., Hazra, S.K., Ramasubramanian, T., Mandal, R.K., Sinha, M.K., Sen, H.S. (Eds.), Jute and Allied Fibre Updates: Production and Technology. Central Research Institute for Jute and Allied Fibres, Barrackpore, Kolka- 
ta, pp. 57-75.

Li, D. (2002). Kenaf production, research and development in China. International kenaf symposium. T. N. USA.

Mahadevan, N., Shivali and Kamboj, P. (2009). Hibiscus sabdariffa Linn.-an overview. Nat. Prod. Rad., $8(1): 77-81$.

Mortan, J. (1987). Roselle. In: Fruits of warm climates. Julia F. Morton, Miami, FL. pp 281-286

Mostafa, H.A.M., Hala, M.S., El-Bassiouny., Hemmat, K.I., Khattab, M. and Sadak, S. (2005). Improving the characteristics of roselle seeds as a new source of protein and lipid by gibberellin and benzyladenine application. J. Appl. Sci. Res., 1: 161-167.

Mukewar, A.M., Zope, J.S. and Lahane, P.S. (1997). Combining ability analysis in kenaf (Hibiscus sabdariffa L.). Indian J. Genet. Plant Breed., 57(2): 161-162.

Ruelas-Hernandez, P.G., Caro-Velarde, F. de J., PerezGonzales, R. and Valdivia-Bernal, R. (2008). Combining ability and heterosis in a diallel cross of Jamaican sorelle (Hibiscus sabdariffa L.). Rivista Chapingo Serie Horticultura., 14(13): 325-330.
Sharma, H.K., Sarkar, M., Choudhary, S.B., Kumar, A.A., Maruthi, R.T., Mitra, J. and Karmakar, P.G. (2016). Diversity analysis based on agro-morphological traits and microsatellite based markers in global germplasm collections of roselle (Hibiscus sabdariffa L.). Ind. Crops Prod., 89: 303-315.

Singh, R.K. and Chaudhary, B.D. (1979). Biometrical methods in quantitative genetics analysis. Kalyani Publishers, New Delhi, India. pp. 304.

Sprague, G.F. and Tatum, L.A. (1942). General vs. specific combining ability in single crosses of corn. J. American Soc. Agron., 34: 923-932.

Tejaswini, R.A.S. and Sarma, M.S. (1995). Heterosis, potence ratio and inbreeding depression in roselle (Hibiscus sabdariffa L. var. altissima). Indian J. Genet. Plant Breed., 55(4): 359-361.

Thirthamallappa, Sheriff R.A. (1992). Combining ability in roselle (Hibiscus sabdariffa L. var. altissima). Indian J. Genet. Plant Breed., 52: 367-368.

Wester, J.P. (1907). Roselle: Its culture and uses. Farmers' Bulletin 307, Department of Agriculture, Bureau of Plant Industry, U.S. 